\title{
Farmers perceptions on impact of water scarcity in Pishin Lora Basin of Balochistan
}

\author{
Zainuddin Kakar ${ }^{1 *}$, Maqsood Ahmad Khan ${ }^{2}$ and Muhammad Zubair \\ $\mathrm{Khan}^{3}$ \\ 1. Faculty of Management Sciences, Balochistan University of Information Technology, Engineering \& \\ Management Sciences (BUITEMS), Quetta-Pakistan \\ 2. Balochistan University of Information Technology, Engineering \& Management Sciences (BUITEMS), Quetta- \\ Pakistan \\ 3. Department of Water Management, The University of Agriculture, Peshawar, Khyber Pakhtoonkhawa -Pakistan \\ *Corresponding author's email: Zainkakar12@yahoo.com \\ Citation \\ Zainuddin Kakar, Maqsood Ahmad Khan and Muhammad Zubair Khan. Farmers perceptions on impact of water \\ scarcity in Pishin Lora Basin of Balochistan. Pure and Applied Biology. Vol. 6, Issue 1, pp293-303. \\ http://dx.doi.org/10.19045/bspab.2017.60027
}

\begin{tabular}{llll}
\hline \hline Received: 29/08/2016 & Revised: 16/02/2017 & Accepted: 22/02/2017 & Online First: 26/02/2017 \\
\hline \hline
\end{tabular}

\section{Abstract}

The present study was undertaken to analyze the impact of water scarcity on farmers' incomes and employment in Pishin Lora Basin. The study is based on primary data which was collected from 300 farmers through a well-structured questionnaire. The main findings of the study are that the persistent water shortage has led to a noteworthy decline in the cultivated farm area, the drying of fruit trees in large numbers, and losses of livestock over the last ten years have caused enormous losses in farmers' incomes and increases unemployment in the area. On the basis of the findings of the study various measures are recommended to overcome water scarcity in the short and long run such as the construction of new dams to store the runoff water; educating the farmers about the use of high efficiency irrigation systems to increase farm level water use efficiency; improve power supplies to the agriculture tube wells; and remove power outages.

Keywords: Farmers perceptions; Impact of water scarcity; Low income; High efficiency irrigation system; Power supply

\section{Introduction}

Water is essential for life and sustainable development, including the preservation of natural environment, alleviation of poverty and hunger. However, many countries including Pakistan are facing the challenge of rapidly growing water demand, driven by increasing population and economic growth [1]. Water in the right quality, amount, time, and place is essential for ecosystems and for economies [2]. Water becoming scarce globally, and water scarcity is taking in increasing important place in water policy discussions, and is often advocated as one in a set of feasible policy options to mitigate the spatial variability in water availability [3]. Many countries have to face the challenge of rapidly growing water demands, driven by an increasing population and economic growth, linked to urbanization, industrialization and mechanism [4]. The resulting water scarcity 
is one of the most pervasive natural resource allocation problem faced by development planners. Hence, water resource management seems to have become one of the important political, social and economic issues of the present century and economists face new challenges of growing water demands and changing laws and institution [5]. Therefore, the need for efficient, equitable and sustainable water allocation policies is evident and new water management studies aim at investigating innovative strategies to yield more efficient water allocation [6].

Pakistan is facing unprecedented water shortage, climate change and poor water management have resulted in exploitation of water at a rate faster than it is replenished, directly contributing to the growing water scarcity crises [7]. The agriculture economy of Pakistan is facing sever challenges due to rapidly growing demand for water resources. Efficient water management is becoming the single most important regional and global resource management challenge, which not only increases the availability of water for agriculture but also saves it for other uses [8]. Water is scarce resource in Pakistan in general and more specifically in the province of Balochistan, where water resource is overexploited and the farmers are facing sever water shortage [9]. Moreover, it has been estimated that the aquifer storage in the Quetta sub-basin will be exhausted in next 13 years in case if no appropriate measures are taken for conservation of groundwater in Pishin Lora basin [10]. Indiscriminate installation of tubewells, inefficient irrigation methods and pumping of water in excess of recharge has caused lowering of water table resulting in the drying of Wells, Karezes and springs. The mining of ground water and lowering of water table is causing a serious concern regarding sustainability of tubewells irrigated agriculture in the tubewells dependent areas of Balochistan. [11]

\section{Study objectives}

To find out farmers' perceptions on impacts of water scarcity on farmers' incomes and employment from agriculture and livestock production.

To suggest measures for controlling water scarcity and increasing farmers' production with available water resources.

\section{Materials and methods}

\section{Description of the study area}

Balochistan province comprising an area of $347,000 \mathrm{~km}^{2}$, the province is situated towards the south-west of Pakistan and is bordered with Iran to the west, Afghanistan and Federal Administrated Tribal Areas (FATA) to the north, and the provinces of Punjab and Sindh to the east. Towards south, the province has a coastline with the Arabian Sea. Despite the largest province of the country, Balochistan represents only about 5 percent of the total population of country. According to 1998 population censes the population of Balochistan was 7 million out of total 140 million.

Climatically, Balochistan ranges from semiarid to hyper-arid condition characterized by scarce and spatially scattered rainfall, and high evaporation rates. Mean rainfall ranges from less than $50 \mathrm{~mm}$ in western deserts to more than $400 \mathrm{~mm}$ in northern highlands, whereas the annual evaporation rate exceeds $2000 \mathrm{~mm}$. The spatial availability of water in the province is 23 percent of that of Pakistan. However, most of the water runs rapidly due to high stream gradients [10]. Agriculture and livestock production are the two dominant sectors contributing to the Balochistan economy, accounting for more than fifty percent of the provincial GDP. The wide agro-ecological diversity of the province permits cultivation of a large number of crops, vegetables, deciduous, and tropical fruits [12]. Irrigated agriculture is depending both on surface and ground water 
resources. The Khirthar and Pat Feeder canals of the Indus Basin irrigation system and flood water that flows through the stream are the important sources of surface water. The groundwater is available for irrigated agriculture through Karezes, Springs, Wells and Tubewells. With the availability of electricity in the 70's from the national grid system, there has been tremendous increase in the number of tubewells, which lowering the water tables. Inefficient water use, wastage of surface water and indiscriminate exploitation of groundwater aggravated the situation, making management of water a real complex, important and a difficult task in Balochistan. The persistent drought during the last decade of $20^{\text {th }}$ centenary had created negative impact on the availability of water and livelihood of rural communities.

Pishin Lora Basin lies in the uplands of Balochistan. Its total area is about 18,133 $\mathrm{Km}^{2}$. On hydrological basis the basin is subdivided into eleven sub-basins; Pishin, Kuchlagh, Quetta, Kolpur, Sardar Khel, Mastung, Shirinab, Patki, Shaanawz, Mangochar, Kalat and Kapoto [13]. According to the census 1998 the population of Pishin Lora Basin was about 2,178,792 of which about $45 \%$ lived in Quetta city. Agriculture, livestock and fruit production are the major sources of income for majority of the farmers in the basin. Both surface and ground water are the major sources of water supply for the fulfillment of both the domestic and non-domestic needs by using different sources like surface water from flood flows and perennial base flow in river, karezes, springs, and tubewells. The number of tubewells in the basin in 2005 were $11,918(10,369$ electric and 1,549 diesel) constituting 44 percent of the total tubewells in Balochistan. In 1991, annual groundwater depletion in the Pishin Lora basin was estimated to be $1.52 \mathrm{~m} /$ year. However due to depletion of groundwater and over- abstraction of groundwater during recent drought, the depletion rate of groundwater increased and the current estimates indicate an annual decline of 1-3 m per year in the alluvial aquifer and up to $20 \mathrm{~mm}$ annual draw down in the hard rock aquifer in Pishin Lora basin [13].

\section{Sampling and data collection}

The aim of the present study is to analyze water scarcity and its impact on the agricultural community in Pishin Lora Basin (PLB). For this purpose, the farmers' community of the area of PLB was taken as target population. Pishin Lora Basin consists of five districts namely, Pishin, Killa Abdullah, Quetta, Mastung and part of Kalat. The primary data were obtained from the farmers through a well-structured and comprehensive questionnaire. The farmers were contacted either in their fields, homes, and community center (Hujras). Stratified random sampling technique was used. Some 105 farmers were interview in district Pishin (Pishin district was divided into two areas, fifty-five farmers in Barshore/Karezat tehsil and fifty farmers in Huramzai/Pishin tehsil). 55 farmers in district Quetta, 50 farmers in district Killa Abdullah, 50 farmers in district Mastung, and 40 farmers were selected from district Kalat. Within each district was further divided in the clusters of Union Councils and farmers within each Union Council were selected to give the spatial coverage to the area.

\section{Results and discussion}

This section is based on the result and discussion of the study. The result shows the farmers' perception about the present water situation and the impact of water shortage on the different sectors of the economy of Pishin Lora Basin (PLB). First sub-section of this section presents farmers' perception about the current status of water in the study area of PLB, after that second sub-section presents the information about the impact of 
water scarcity on different enterprises. The details are as follows:

\section{Current status of water resources in} Pishin Lora Bain

Pishin Lora Basin lies in arid zone of Balochistan. With low rain fall and high evaporation rate, the groundwater is the main source of water supply yet considered a limited source of water for fulfilling the irrigation needs of the agriculture sector. Before 1980s, when there was no electricity in many of the rural area, the traditional sources i.e., well, spring and karezes were mainly used for the irrigation purposes. However, with the passage of time starting of electrification program of rural areas led to the replacement of above mentioned traditional sources with the tube wells. This development led to the over exploitation of groundwater and resulted in the depletion of water table. During the survey it was noted that although the farmers are aware of the rapid decline of water table. But, as groundwater is the main source of irrigation but they have no alternative source of irrigation. Farmer's views in response to quarries about the rate of decline in water table are presented as Figure 1. Figure 1 shows the farmers response about the annual depletion of water table in study area over the last ten years. It can be seen that majority of the farmers i.e. 116 out of 300 mentioned that it declined 16 to 20 feet over the last ten years. Similarly, 74 farmers pointed out that it declined 26 to 30 feet, 24 farmers mentioned that it declined 21 to 25 feet and the remaining 30 farmers stated that the rate of depletion was 30 feet over the last ten years. Only 35 farmers mentioned that the rate was 6 to 10 feet, 15 stated 11 to 15 feet and 6 stated 5 feet over the last years. Overall out of 300 farmers 244 stated that the groundwater is depleting $25 \%$ annually which is very high rate especially in an arid area of PLB. For getting more detailed information about what the farmers think about the rapid decline of groundwater over the next 5 years. The following response was received from the 300 sample farmers given in Figure 2.

Figure 2 shows the response of the farmers about the expected water depletion rate over the next of 5-year period. Out of 300 respondents $83 \%$ farmers' respondent that it will go down further, $13 \%$ replied that it will remain stable, whereas only $4 \%$ replied that they have no idea about the future water depletion.

Further, when it was asked from the respondents that what they think, in how many years the groundwater scarcity will reach to the crises level (hard to get water), the following responses given in Figure 3 were received.

Figure 3 shows that out of 300 farmers $71 \%$ believe that given the rapidly declining water levels, the crises level of groundwater may come in the next ten years and $15 \%$ mentioned that in next twenty years, whereas $14 \%$ replied that they don't have any idea about it. 


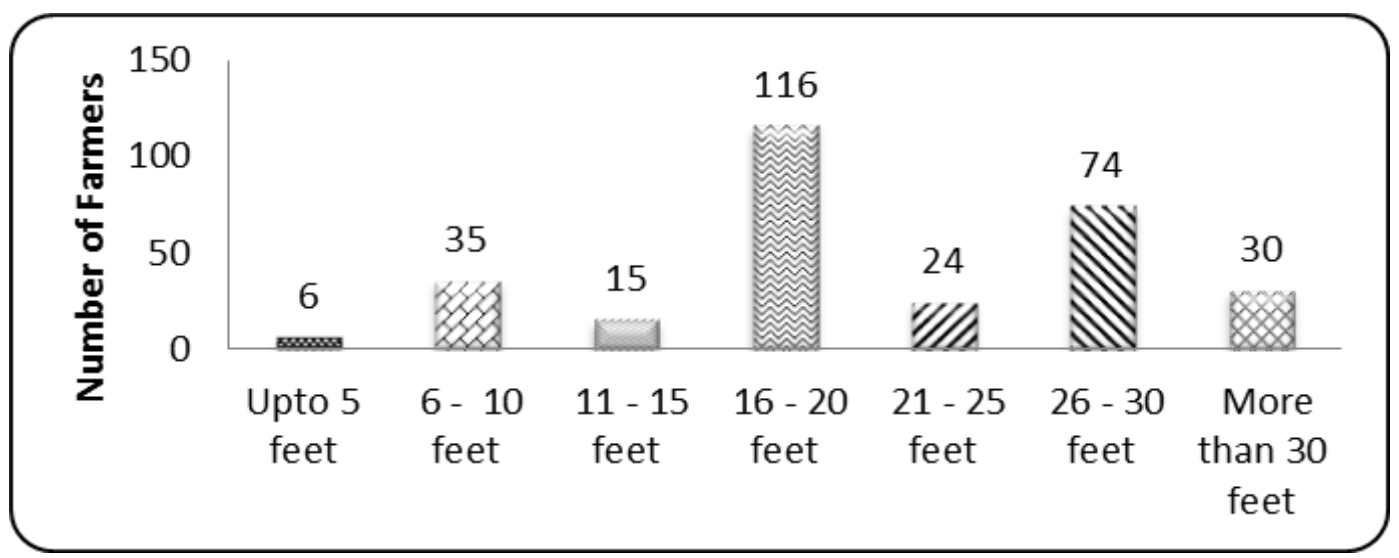

Figure 1. Farmers' Perception about depletion of groundwater over the last ten years (Sources: Field Survey)

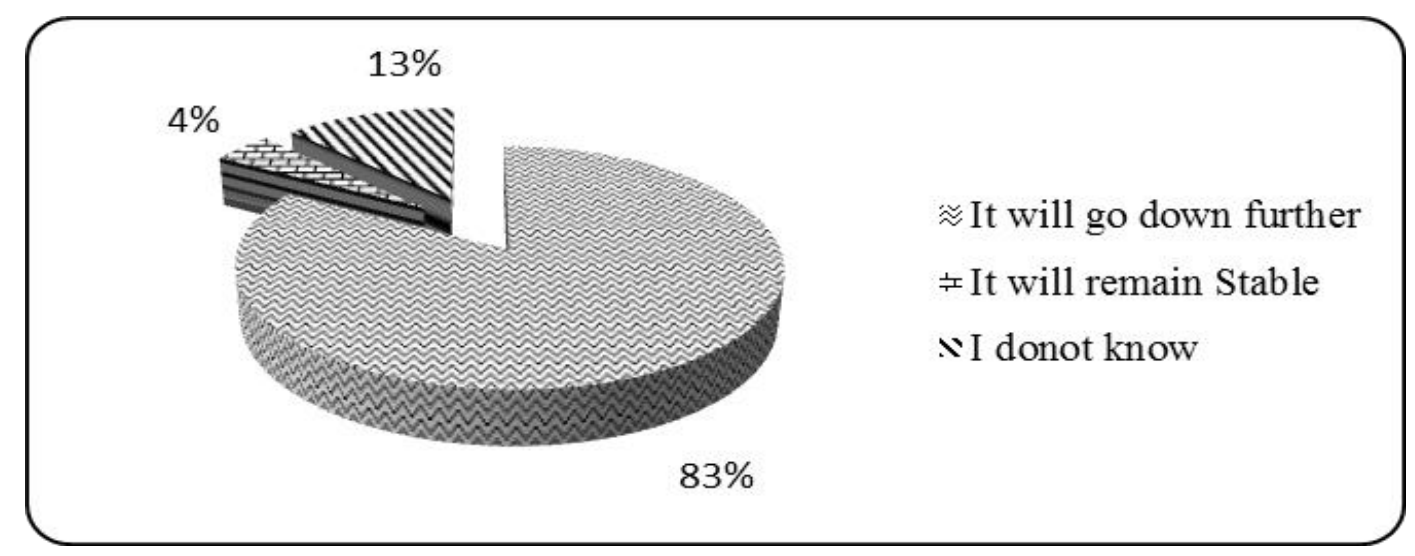

Figure 2. Farmers' perception about depletion of groundwater in next five years (Sources: Field Survey)

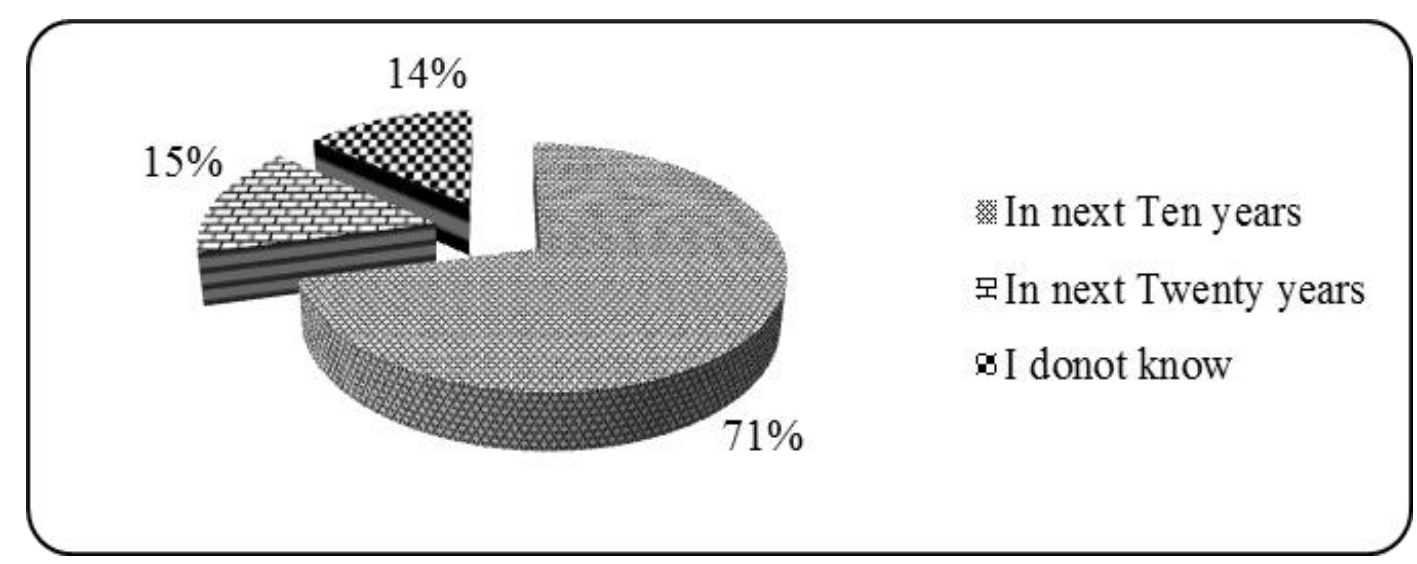

Figure 3. Farmers' perceptions about when the groundwater is expected to vanish (Sources: Field Survey) 
In short, the above Figures show that water scarcity is a major problem in the study area. Also in spite the fact that the farmers knew about the rapid water table decline in the PLB, but, they have still continued pumping of groundwater.

\section{Impacts of water scarcity}

From the result of survey, it was revealed that water scarcity has great impacts on the economic and social life of people in PLB. The present amount of water is not enough for meeting the demand for irrigation of agriculture sector as per farmers' estimates, which can be seen in Figure 4.

Figure 4 shows the balance between the available and required amount of seasonal water resources for the orchards. It can be seen that according to the farmers' information the available water is not enough to meet the requirement of water for orchards. The Figure 4 shows that the average available water in the region is above $1000 \mathrm{~mm}$, whereas the required amount of water is almost $1400 \mathrm{~mm}$ for all the farmers in the area. Like the orchards, the available amount of water is also short for the vegetable which are shown in Figure 5 . Figure 5 highlights the difference between the available and required amount of water for vegetables. It is clear that required amount of per season water for the vegetables is almost $700 \mathrm{~mm}$ against the available amount of water which is not only above $400 \mathrm{~mm}$ led to the decline in the farmers' income from vegetables.

Likewise Figure 6 shows the balance between the available and required amount of water for the wheat in PLB. An interesting thing which has been noted during the survey is that the available amount of water for the irrigation of wheat is greater than the required amount of water showing that that the farmers can be benefited from the wheat income as the fact shows that the horticulture sector in PLB seems to be collapsing in the coming few years because most of the tubewells have been dried out.

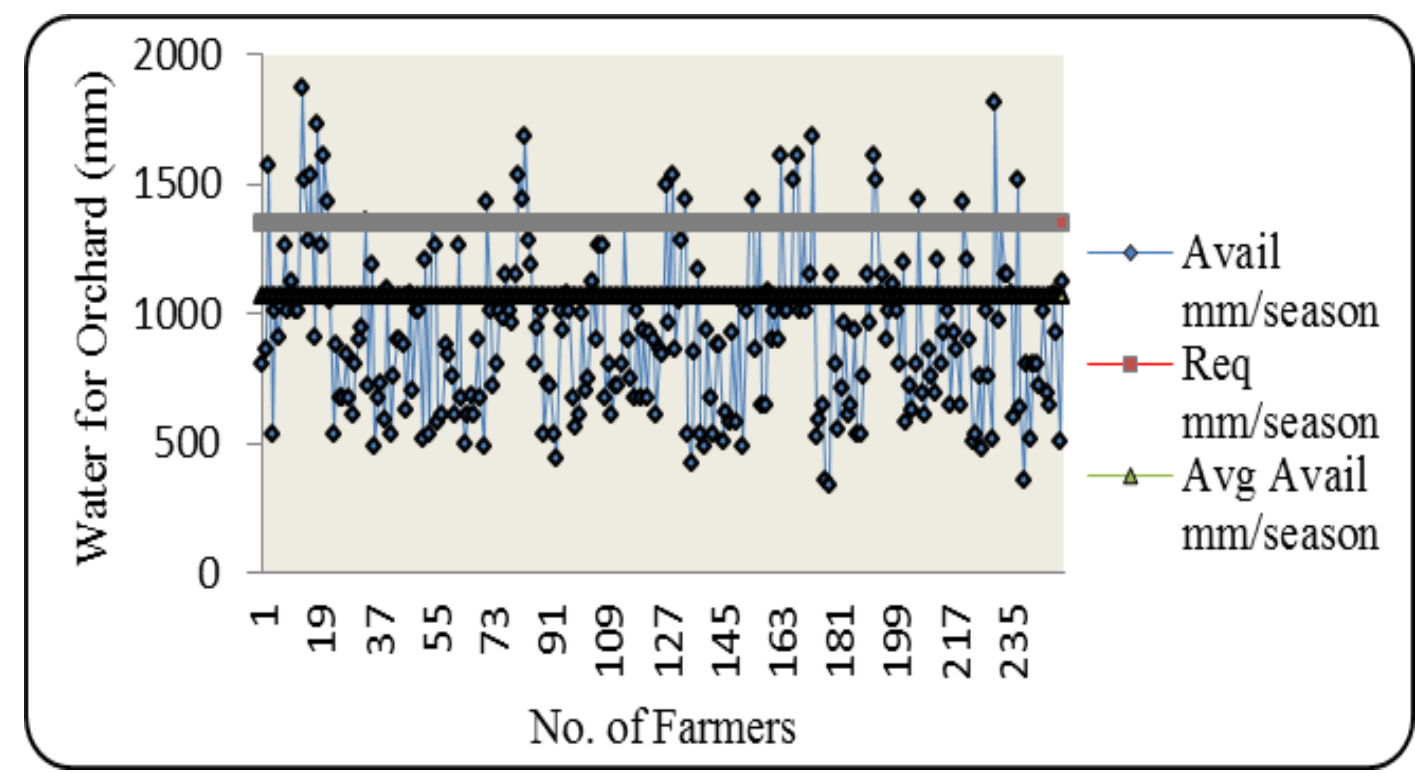

Figure 4. Water Availability and Requirement for Orchards in PLB (Sources: IUCN, Quetta and Field Survey) 


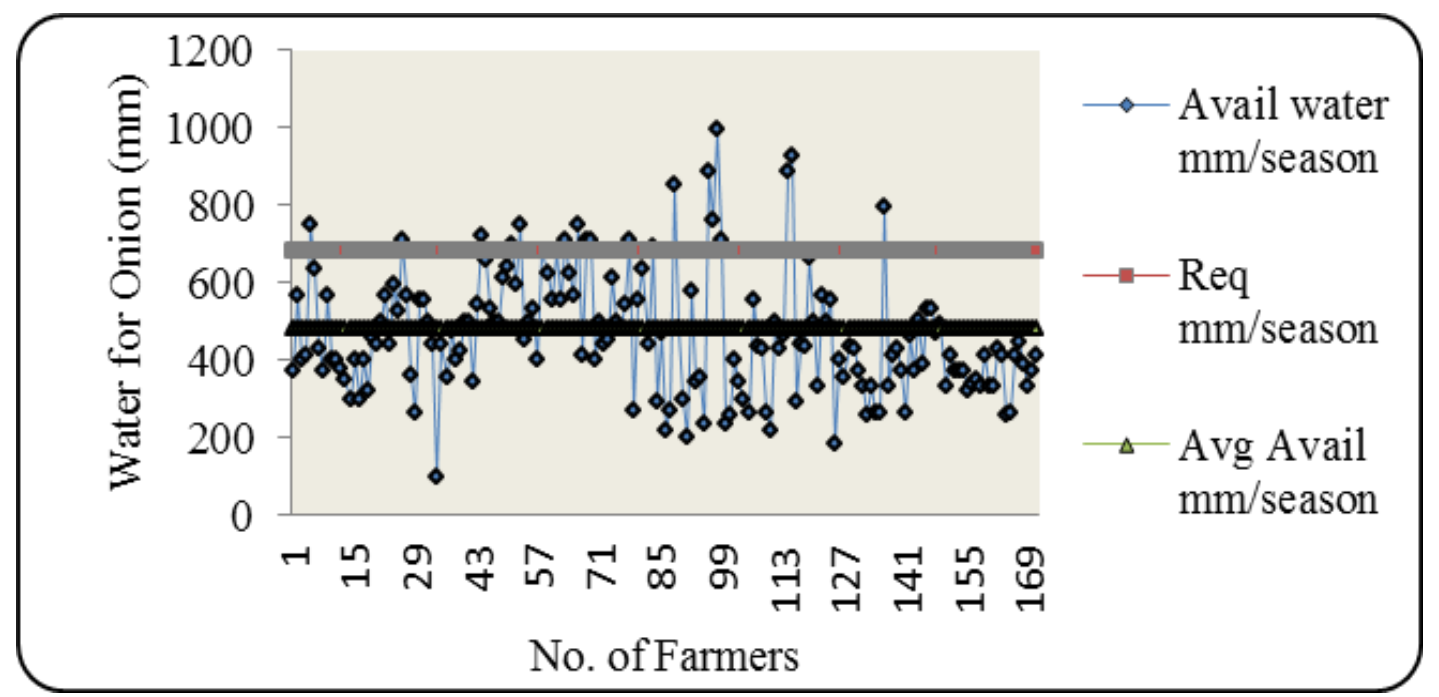

Figure 5. Water Availability and Requirement for Vegetables in PLB (Sources: IUCN, Quetta and Field Survey)

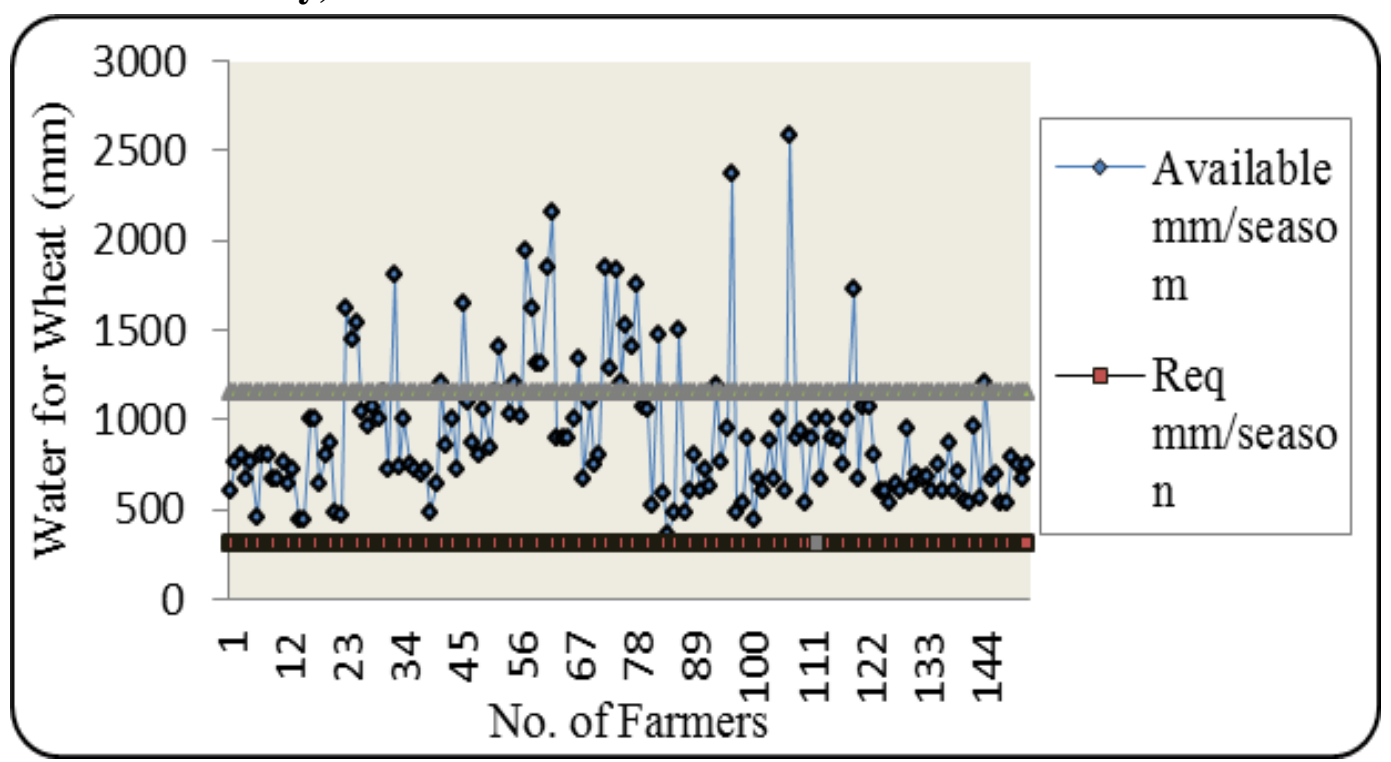

Figure 6. Water Availability and Requirement for Wheat in PLB (Sources: IUCN \& Field Survey)

\section{Loss in farmers' income due to water scarcity over the last ten years}

Due to water scarcity, a decline in land cultivation and, productivity losses has caused a significant loss in farmers' incomes. The details of losses over the last ten years as reported by sample farmers are given as Figure 7 . It can be seen that there is a huge loss of income to the farmers in all the districts i.e. Pishin, Killa Abdulla, Quetta, Mastung and Kalat districts. The results show that the combine losses in all the districts exceed Rs.300 million. In Barshore/Karezat tehsil of district Pishin some 55 farmers reported that their loss in income due to water scarcity was Rs.77.2 million. Similarly, in district Pishin some 50 farmers reported that their loss in income due to water scarcity was Rs.64.1 million, while in Killa Abdullah district some 50 farmers reported that their loss in income due to water scarcity was Rs.53.3 million. In 
Quetta district some 55 farmers reported that their loss in income due to water scarcity was Rs.44.5 million. In Mastung district 50 farmers said that their loss in income due to water scarcity is Rs.49 million. In district Kalat some 40 sample farmers reported that their loss in income due to water scarcity was Rs.59.1 million.

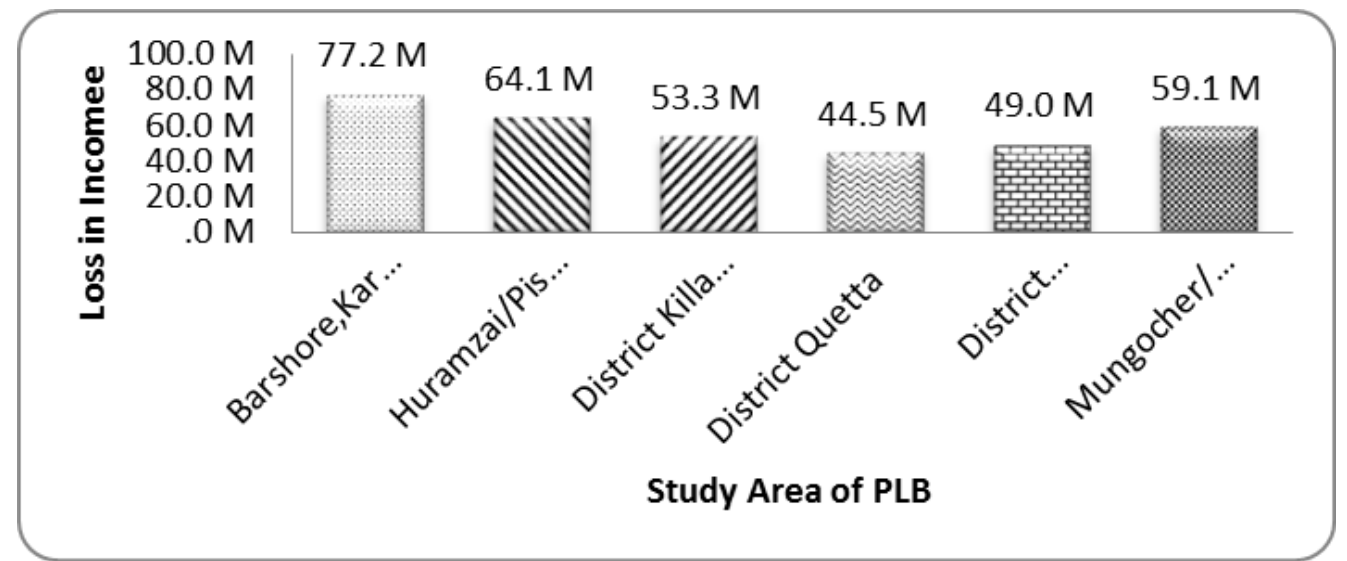

Figure 7. Farmers' perception about the loss in income (Rs in Millions) over the last ten years (Source: Field Survey)

\section{Orchard trees dried due to water} shortage over the last ten years

The farmers reported that because of the water scarcity, thousands of trees of different fruits dried over the last ten years. According to the Agriculture department of Balochistan, more than $40 \%$ of apples, peach and apricots trees have dried in the different parts of the uplands of Balochistan. The extent of losses reported by farmers in terms of drying of fruit trees is shown as Figure 8.

Figure 8 shows the farmers response on the number of trees dried because of the water scarcity in PLB. Around 40 farmers mentioned that the number of their trees dried were 401 to 500. Similarly, at least 30 farmers mentioned that the numbers of their trees dried were 201 to 300 ; more than 25 farmers mentioned that the dried trees numbered 101 to 200. Likewise, 30 farmers mentioned that the number of their dried trees were from 801 to 1000. Similarly, about 15 farmers pointed out that their more than 1000 trees dried because of water scarcity.

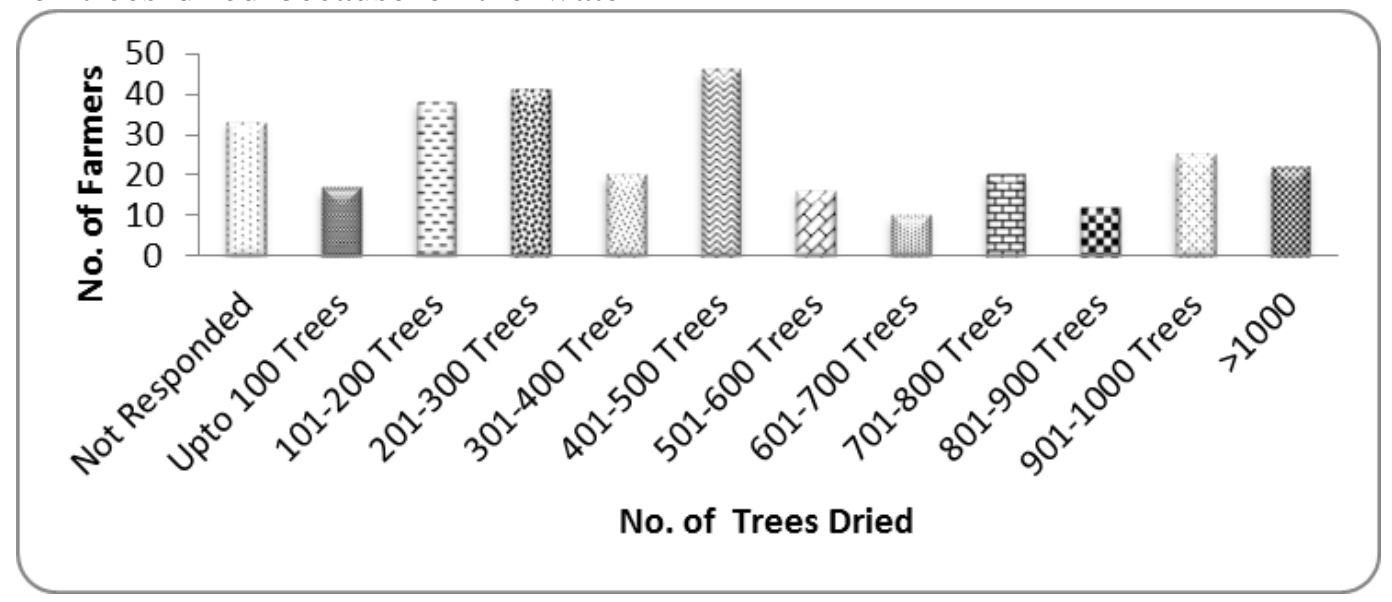

Figure 8. Farmers' perception about the trees dried over the last ten years (Sources: Field Survey) 


\section{Impact of water scarcity on livestock production}

According to [14], almost 92\% area of Balochistan is providing grazing to around 20 million small ruminants. However, because of the wood extraction and water shortage the farmers also suffered from the loss of their livestock. The details are given in Figure 9 which is as follows: The Figure results show that because of the persistent and long period of drought in the area and water scarcity the livestock of the farmers were died. Around 60 farmers mentioned that the deaths of their livestock numbered were 21 to 30 . Similarly, some 50 farmers stated that they lost 11 to 20 livestock, while some 40 farmers mentioned their loss in the range of 30 to 40 , and 20 farmers mentioned that their livestock losses were 41 to 50 . Similarly, around 10 farmers mentioned that they lost more than 50 livestock.

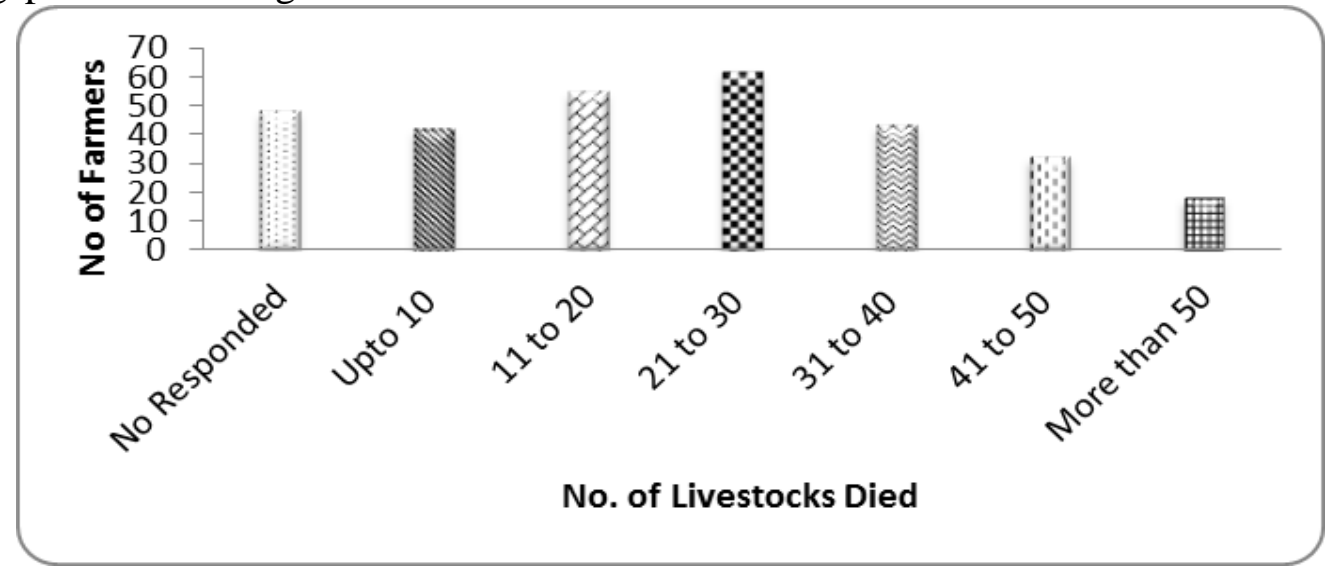

Figure 9. Farmers' perception about the Animals died due to drought and water scarcity (Sources: Field Survey)

\section{Impact on employment}

Water scarcity also affected the employment rate in study area of PLB. The farmers' perception about the unemployment is given in Figure 10. Figure 10 show the rising unemployment in PLB resulted by water scarcity. Some 102 farmers figured out that because of water scarcity the unemployment rate in the region was in the range of 41 to 50 percent. Similarly, 188 farmers stated that the unemployment rate was in the range of 51 to 70 percent.

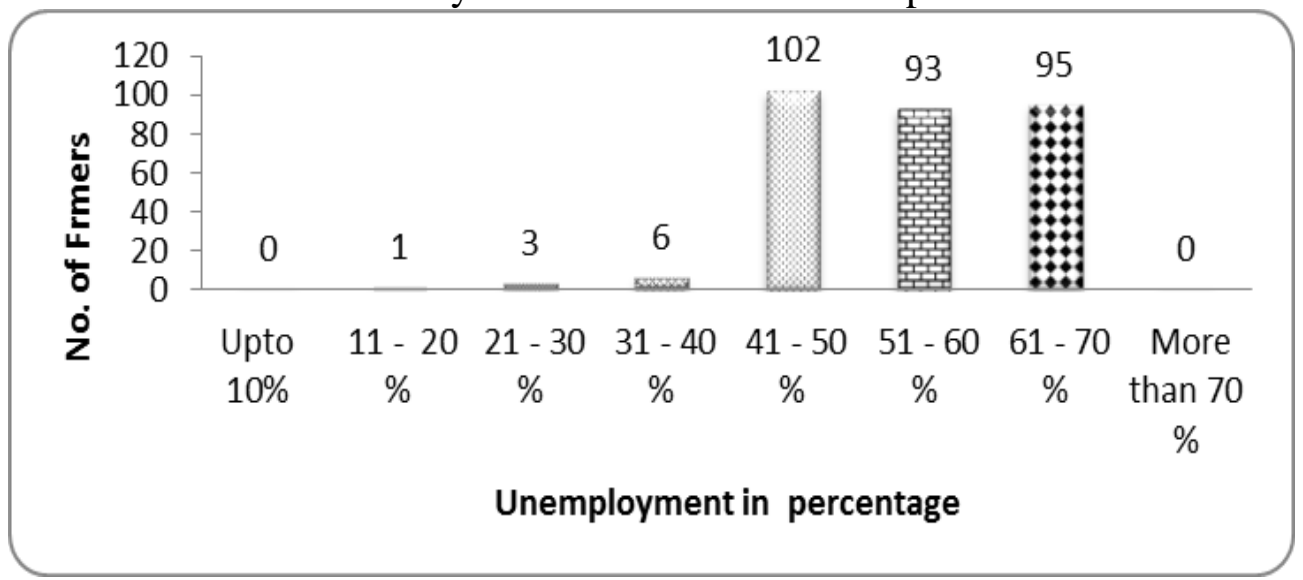

Figure 10. Farmers' perception about loss of employment caused by water scarcity (Sources: Field Survey) 
In short, the above Figures show that the availability of water for irrigation is not in accordance with the demand for irrigation, resulting in huge losses to the farmers' overall incomes from the livestock, crops, fruits and employment etc.

\section{Conclusions and recommendations}

The main findings of the study are that the groundwater has been vanishing quickly in PLB. When the farmers were asked about the current and future expected rate of water depletion, majority of the farmers mentioned that the groundwater depletion rate has been between 16 to 20 feet during the last ten years and may be disastrous in the coming years. Regarding to the impact of water scarcity on the total incomes of the farming community from agricultural sector, it was found that the available supply of water is short against required annual demand for agricultural production. This water shortage has led to the dryness of tube wells, reduction in cultivated land, dryness and uprooting of fruit bearing mature fruit trees and consequently enormous loss in farmers' incomes, increased unemployment and mortality of livestock. On the basis of study results the following suggestions are made for improvement.

Impose ban on installation of new agricultural tubewells, however, the installation of more tubewells for drinking purpose should be allowed only in case of replacement of dried tubewells.

During survey it was also been noted that most of the surface water especially the rain water get waste in the rivers. It is recommended that the government should construct new dams for the rain water harvesting.

The Quetta Electric Supply Corporation (QESCO) may be made responsible for providing reliable power supply to the farmers and other consumers involved in pumping of groundwater and irrigation related activities.
Seminars, workshops and training on farm water management approach in order to bring awareness about the benefits of water application efficiency and the disadvantage of over irrigation.

\section{Authors' contributions}

Conceived and designed the experiments: $\mathrm{Z}$ Kakar, Performed the experiments: Z Kakar \& MA Khan, Analyzed the data: MA Khan, Contributed reagents/ materials/ analysis tools: Z Kakar \& MZ Khan, Wrote the paper: Z Kakar.

\section{References}

1. Halcrow (2007). Supporting Public Resource Management in Balochistan, Basin-wide Water Resources Availability and Use. Irrigation and Power Department, Government of Balochistan, Royal Netherland Government. Halcrow Pakistan (Pvt) in association with Cameos.

2. Ward FA \& Velazquez MP (2008). Water conservation in Irrigation Can Increase Water Use. National Academy of Science U.S.A. 105(47): 18215-18220.

3. Lenzen M, Moran D, Bhaduri A, Kenemoto K, Bekchanov M, Geschke A \& Foran B (2013). International Trade of Scarce Water. Ecological Economics 94: 78-85.

4. King N (2004). The Economic Value of Water in South Africa. University of Cape Town Press, Cape Town 207-238.

5. Louw DB (2002). The Development of a Methodology to Determine the True Value of Water and the Impact of a Potential Water Market on the Efficient Utilization of Water in the Berg River Basin. WRC Report No. 943/1/02. Water Research Commission, Pretoria.

6. Walter T, Kloos J \& Tsegai D (2011). Option for Improving Water Use Efficiency under Worsening Scarcity: evidence from the Middle Olifants SubBasin in South Africa. Water SA 37(3): 357-370. 
7. Khair SM \& Culas RJ (2013). Rationalizing water management policies: tubewells development and resource use sustainability in Balochistan region of Pakistan. Int J Water 7: 2013.

8. Choudhary MA, Lodhi AS \& Ahmad M (2008). A Comparative Study of Cost of Production and Decision Making Analysis in Case of Onion and Sunflower Crops in Quetta District. Sarhad J Agric 24(3): 470-478.

9. Nasurullah K, Ahmad M, Malghani MGK \& Kakar E (2011). Socio-Economic Effects of Water Scarcity in Tehsil Karezat District Pishin Balochistan. Journal of Applied \& Emerging Science 2(2).

10. Bhatti SS, Khattak MU \& Roohi R (2008). Planning Water Resource Management in Pishin Lora River Basin of Balochistan Using GIS/RS Techniques. ICAST (2): 91-97.

11. Khair SM, Mushtaq S \& Smith KR (2014). Ground Governance in a Water-
Starved Country: Public Policy, Farmers' Perceptions, and Drivers of Tubewells Adoption in Balochistan Pakistan.

12. Bajoi AH (2004). Report on reorganization of Agriculture Research and Extension Balochistan University of Information Technology Engineering and Management Sciences Quetta.

13. Halcrow (2008). Supporting Public Resource Management in Balochistan, Pishin Lora Basin Management Plan: Final Report. Irrigation and Power Department, Government of Balochistan, Royal Netherland Government. Halcow Pakistan (Pvt) in association with Cameos.

14. Ahmad S, Hussain Z, Qureshi AS, Majeed R \& Saleem M (2004). Drought Mitigation in Pakistan: Current Status and Option for Future Strategies. International Water Management Institute, Working Paper No. 85. 